\title{
BENIGN AND MALIGNANT NEOPLASIAS IN 261 NECROPSIES FOR HIV-POSITIVE PATIENTS IN THE PERIOD OF 1989 TO 2008
}

Adilha Rua MICHELETTI(1), Ana Carolina Sandoval MACEDO(2), Gisele BARBOSA E SILVA(2), Ana Cristina Araújo Lemos da SILVA(3), Mário Leon SILVA-VERGARA(4), Eddie Fernando Cândido MURTA(5) \& Sheila Jorge ADAD(6)

\begin{abstract}
SUMMARY
Considering that there are some studies with autopsies from AIDS describing only malignant neoplasias and that changes can occur after the introduction of Highly Active Antiretroviral Therapy (HAART), our objectives were to analyze the frequency of benign and malignant neoplasms in AIDS patients in the periods of both pre- and post-HAART. This is a retrospective study with 261 autopsies of HIV-positive patients between 1989 and 2008 in Uberaba, Brazil. Sixty-six neoplasms were found (39 benign, 21 malignant and six premalignant) in 58 patients. The most frequent malignant neoplasms were lymphoid, in $2.7 \%$ (four Non-Hodgkin lymphoma, one Hodgkin, one multiple myeloma and one plasmablastic plasmacytoma), and Kaposi`s Sarcoma, in 2.3\% (six cases). The most frequent benign neoplasms were hepatic hemangiomas in $11(4.2 \%)$ of 261 cases and uterine leiomyoma in 11 (15.7\%) of 70 woman. In the pre-HAART period eight $(9.8 \%)$ benign neoplasias and four $(4.9 \%)$ malignant occurred in 82 patients; in the post-HAART period, $29(16.2 \%)$ benign and $17(9.5 \%)$ malignant were present; however, the differences were not significant. We conclude that the introduction of HAART in our region doesn't look to have modified the frequency of neoplasms occurring in patients with HIV.
\end{abstract}

KEYWORDS: HIV; AIDS; Neoplasm benign; Neoplasm malignant; Necropsy.

\section{INTRODUCTION}

The human immunodeficiency virus (HIV) infection is associated with the progressive deterioration in cell immunity that culminates in acquired immunodeficiency syndrome (AIDS). The decline in cell immunity explains two complications in patients with AIDS: infections and neoplasia ${ }^{2}$.

Kaposi's sarcoma (KS), Non-Hodgkin lymphoma (NHL) and carcinoma of the uterine cervix are the most frequent neoplasms in AIDS patients. These are considered to be defining diseases for AIDS $^{6,10,16,18}$. According to some authors, other types of neoplasia also seem to be more common among HIV-positive individuals. Among these types are: squamous cell carcinoma of the head/neck and anal region, plasmacytoma, melanoma, small cell lung cancer, basal cell carcinoma, Hodgkin's lymphoma (HL) and germinative tumors ${ }^{5,9,11,13,30,34}$. The neoplasms associated with AIDS occur more frequently in developed rather than in underdeveloped countries ${ }^{12,23}$. LUCAS et al. ${ }^{26}$ described seven cases of B-cell NHL (2.8\%) among 247 necropsies on HIV-positive patients in Africa and commented that the rarity of this tumor in this continent is associated with the short survival rate of African patients.

Antiretroviral therapy has given rise to changes in the morbidity and mortality rates among HIV patients. In addition to reducing the occurrence of opportunistic infections, it has also affected the occurrence of neoplasms that are correlated with $\operatorname{AIDS}^{20,24,28}$. Some studies have shown decreases in KS and primary NHL of the central nervous system (CNS) and less significant decreases in systemic $\mathrm{NHL}^{17}$. On the other hand, other studies have not demonstrated any change in the frequency of KS, and slight increases in the frequencies of NHL, HL and different types of carcinoma $a^{4,5,20,24,28}$. The occurrence of neoplasia of the uterine cervix has not undergone any significant change since the use of highly active antiretroviral therapy ${ }^{8,15}$.

Studies with large numbers of necropsies on AIDS patients in the literature have described overall findings relating to infections and neoplasms, giving greater emphasis to infections and malignant tumors. The frequency of malignant neoplasms is generally less than $20 \% 1,20,21,24,31,33,35$. In Brazil, there are two reports on the frequency of malignant neoplasia in autopsied AIDS patients: BORGES et al. ${ }^{7}$ found five $(9.6 \%)$ cases in 52 necropsies and CURY et al. ${ }^{12}$ identified three $(3.3 \%)$ in 92 necropsies. However, we didn't find works describing benign neoplasms in necropsies of patients with HIV infection.

We decided therefore, to evaluate the necropsies of HIV positive patients performed in a teaching hospital in Brazil between 1989 and

(1) Adjunct Professor in the Discipline of Special Pathology, UFTM School of Medicine, Uberaba, MG, Brazil.

(2) Scientific career introductory bursary-holder.

(3)Assistant Professor in the Discipline of Special Pathology, UFTM School of Medicine, Uberaba, MG, Brazil.

(4) Adjunct Professor in the Discipline of Infectious and Parasitic Diseases, UFTM School of Medicine, Uberaba, MG, Brazil.

(5) Titular Professor of the Discipline of Gynecology and Obstetrics, UFTM School of Medicine, Uberaba, MG, Brazil.

(6) Associate Professor in the Discipline of Special Pathology, UFTM School of Medicine, Uberaba, MG, Brazil.

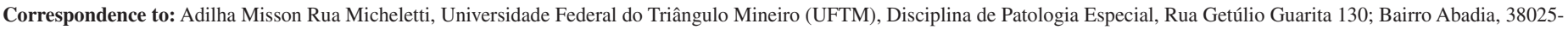
440 Uberaba, MG, Brasil. Tel: +55.34.3318-5152, Fax: +55.34.3318-5846. E-mail: adilharua@ yahoo.com.br 


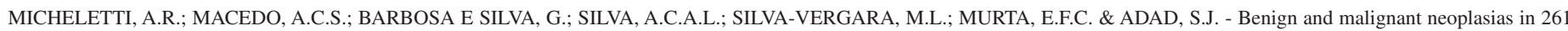
necropsies for HIV-positive patients in the period of 1989 to 2008. Rev. Inst. Med. Trop. São Paulo 53(6): 309-14, 2011.

2008 (261 consecutive cases), describing all benign and malignant neoplasms, in an attempt to evaluate the prevalence of malignancies in AIDS patients in our country and see if some benign neoplasia would come into contact with HIV infection. For comparison, we used the prevalence of malignant neoplasia in other studies of HIV positive patients and for the benign neoplasia we used the prevalence among the general population, since we didn't find studies describing benign tumors associated with HIV infection. We also compared the frequency of neoplasms before and after the introduction of highly active antiretroviral therapy (HAART).

\section{MATERIAL AND METHODS}

This was a retrospective study on necropsies performed on HIV positive patients at the University Hospital in Uberaba, Minas Gerais, Brazil, between January 1989 and December 2008. Over this period, 1,785 necropsies were carried out, of which 261 (14.6\%) were on patients who had been found to be serologically positive for HIV. There were no cases of the congenital transmission of HIV.

The neoplasias were described in relation to the benign or malignant type, sex and age of the patients. The cases were separated in two groups according to the date of necropsy if before or after the introduction of HAART (before or after 1997 in Uberaba, respectively), in order to assess whether there had been any increase or decrease in the number of neoplasia occurrences with the use of this medication.

We revised slides of all the tumors; usually slides are done from every organ including the uterine cervix in all necropsies; we microscopically analyzed the penis when injuries appeared on the macroscopy view. The classification of the tumors were done on a histological basis and when necessary with immunohistochemical analyses (leukocyte common antigen, CD20, CD3, desmin, actin 1A4, Myo D1, myogenin, CD38, CD79a, Kappa, Lambda, cytokeratin AE1/AE3, epithelial membrane antigen, carcinoembryonic antigen, HMB-45 and protein S-100).

The data relating to neoplasia frequencies before and after the introduction of HAART were analyzed using the $\mathrm{X}^{2}$ test or Fisher's exact test. The mean ages in the total HIV group and HIV with neoplasia group were compared using Student's t- test or Mann-Whitney test. Differences were taken to be significant when the p-value was less than 0.05 . The procedures in the present study were in accordance with and approved by the local committee of ethics in research.

\section{RESULTS}

Out of the 261 necropsies performed on HIV positive patients, 191 $(73.2 \%)$ were male. The mean age was $35.3 \pm 10.7$ years, ranging from 16 to 69 years. Neoplasias were found in $58(22.2 \%)$ of the 261 necropsies. Table 1 presents benign and malignant neoplasias in relation to age and sex. There tended to be a common occurrence of patients with neoplasms which were older than the total HIV group $(p=0.0176)$, females with neoplasms older than the female HIV group $(p=0.0221)$ and of female patients with malignant neoplasms which were older than females with benign neoplasms $(p=0.0493)$.

In the 58 HIV patients with neoplasia, 66 tumors were detected, of which 39 were benign, 21 malignant and six intraepithelial [one cervical intraepithelial neoplasia (CIN) grade I, two CIN II, one in situ carcinoma of glans and two condylomas of the penis]. Eight patients had two neoplasms: two patients with two benign neoplasias and six with one benign and one malignant neoplasia. Tables 2 and 3 summarize the data

Table 1

Comparison between the total HIV group and the HIV with neoplasia group in relation to sex and age

\begin{tabular}{|c|c|c|c|c|c|}
\hline \multirow{2}{*}{ HIV } & \multirow{2}{*}{$\mathrm{n}$} & \multicolumn{4}{|c|}{ Age } \\
\hline & & mean & $( \pm)$ & minimum & maximum \\
\hline Total HIV group & 261 & 35.3 & 10.7 & 16 & 69 \\
\hline Male & 191 & 35.6 & 11 & 16 & 69 \\
\hline Female & 70 & 34.7 & 9.9 & 20 & 62 \\
\hline HIV with neoplasm & 58 & 38.5 & 11.1 & 16 & 65 \\
\hline Male & 36 & 37.4 & 12.3 & 16 & 65 \\
\hline Female & 22 & 40.2 & 9.1 & 21 & 56 \\
\hline HIV with benign neoplasm & $37 *$ & 39.9 & 9.2 & 24 & 65 \\
\hline Male & 20 & 38.4 & 10.8 & 24 & 65 \\
\hline Female & 17 & 41.6 & 6.9 & 33 & 56 \\
\hline HIV with malignant neoplasm & $21 *$ & 36.5 & 12 & 16 & 61 \\
\hline Male & 17 & 33.8 & 11.5 & 16 & 61 \\
\hline Female & 04 & 48.3 & 5.6 & 41 & 54 \\
\hline
\end{tabular}

* Six patients had one benign and one malignant neoplasm. Six patients had intraepithelial neoplasm, not considered here. HIV: human immunodeficiency virus; $\mathrm{n}$ : number of cases. Mann-Whitney test: total HIV versus HIV with neoplasm $\boldsymbol{p}=\mathbf{0 . 0 1 7 6}$; Student's test: HIV male versus HIV with neoplasm male $p=0.3572$; HIV female versus HIV with neoplasm female $\boldsymbol{p}=\mathbf{0 . 0 2 2 1}$; Mann-Whitney test: HIV with benign neoplasm versus with malignant neoplasm $p=0.1049$; male with benign neoplasm versus male with malignant neoplasm $p=0.0874$; female with benign neoplasm versus female with malignant neoplasm $\boldsymbol{p}=\mathbf{0 . 0 4 9 3}$ 


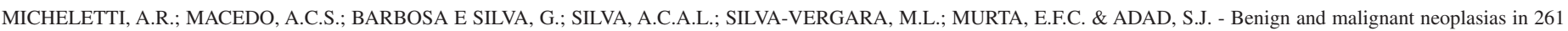
necropsies for HIV-positive patients in the period of 1989 to 2008. Rev. Inst. Med. Trop. São Paulo 53(6): 309-14, 2011.

Table 2

Benign neoplasias in HIV positive patients according to age and sex

\begin{tabular}{lcccc}
\hline Neoplasia & $\mathrm{n}$ & $\begin{array}{c}\% \text { of total } \\
\text { HIV }\end{array}$ & $\begin{array}{c}\text { Age } \\
\text { (min-max) }\end{array}$ & $\begin{array}{c}\text { Sex } \\
\text { M:F }\end{array}$ \\
\hline Hepatic hemangioma & 11 & $4.2 \%$ & $24-57$ & $10: 1$ \\
Uterine leiomyoma & 11 & $15.7 \% *$ & $34-51$ & - \\
Renal adenoma & 3 & $1.2 \%$ & $33-43$ & $1: 2$ \\
Renal medullary fibroma & 3 & $1.2 \%$ & $32-44$ & $3: 0$ \\
Follicular thyroid adenoma & 2 & $0.8 \%$ & $41-56$ & $0: 2$ \\
Lipoma of large bowel & 2 & $0.8 \%$ & $44-47$ & $2: 0$ \\
Adrenal adenoma & 1 & $0.4 \%$ & 38 & $0: 1$ \\
Atrial lipoma & 1 & $0.4 \%$ & 37 & $1: 0$ \\
Benign ovarian teratoma & 1 & $1.4 \% *$ & 38 & - \\
Gastric benign GIST & 1 & $0.4 \%$ & 40 & $1: 0$ \\
Meningioma & 1 & $0.4 \%$ & 65 & $1: 0$ \\
Papilloma of urinary bladder & 1 & $0.4 \%$ & 34 & $0: 1$ \\
Pituitary adenoma & 1 & $0.4 \%$ & 45 & $1: 0$ \\
\hline
\end{tabular}

$\mathrm{n}$ : number of cases; min-max: minimum-maximum age; M:F male and female; GIST: gastrointestinal stromal tumor. *Calculated according to total 70 woman.

Table 3

Malignant neoplasias in HIV positive patients according to age and sex

\begin{tabular}{lcccc}
\hline Neoplasia & $\mathrm{n}$ & $\begin{array}{c}\% \text { of total } \\
\text { HIV }\end{array}$ & $\begin{array}{c}\text { Age } \\
\text { (min-max) }\end{array}$ & $\begin{array}{c}\text { Sex } \\
\text { M:F }\end{array}$ \\
\hline Lymphoid neoplasias & 7 & $2.7 \%$ & $16-54$ & $4: 3$ \\
Kaposi Sarcoma & 6 & $2.3 \%$ & $24-61$ & $6: 0$ \\
Gastric adenocarcinoma & 2 & $0.8 \%$ & $29-52$ & $2: 0$ \\
Gastric malignant GIST & 1 & $0.4 \%$ & 32 & $1: 0$ \\
Hepatocarcinoma & 1 & $0.4 \%$ & 37 & $1: 0$ \\
Intestinal adenocarcinoma & 1 & $0.4 \%$ & 47 & $0: 1$ \\
Malignant testicular teratoma & 1 & $0.5 \% *$ & 26 & - \\
Papillary thyroid carcinoma & 1 & $0.4 \%$ & 27 & $1: 0$ \\
Retroperitoneal embryonal & 1 & $0.4 \%$ & 26 & $1: 0$ \\
carcinoma & & & & \\
\hline
\end{tabular}

GIST: gastrointestinal stromal tumor; $\mathrm{n}$ : number of cases; min-max: minimummaximum age; M:F male and female. *Calculated according to total $191 \mathrm{man}$. Six cases of intraepithelial neoplasias (three cervix uterine and three glans tumors) were not considered in this table.

relating to the benign type and malignant neoplasias observed, distributed by gender and age. There were 39 benign neoplasms in 37 patients, the most frequent being 11 hepatic hemangiomas (10 men and one woman) and 11 uterine leiomyomas.

Malignant neoplasm was responsible for the death of $18(6.9 \%)$ out of 261 total HIV positive patients. The neoplasms relating to death were: six KS, four NHL, one HL, one multiple myeloma, two gastric adenocarcinoma, one embryonic carcinoma, one hepatocellular carcinoma, one intestinal adenocarcinoma and one malignant testicular teratoma. Five of these 18 patients had HIV without signs of AIDS: one 54-year-old woman with HL, one 26-year-old man with embryonic carcinoma, one 52-year-old man with gastric adenocarcinoma, one 47-year-old woman with intestinal adenocarcinoma and one 26-year-old man with malignant testicular teratoma.

The neoplasms classically considered to be related to AIDS were: four cases of primary diffuse large B-cell NHL of the CNS; three men aged 16, 32 and 48-years-old and one woman aged 41-years-old. NHL was not diagnosed in any of the four patients before their deaths. Three other lymphoid neoplasias were seen: one HL, one plasmablastic plasmacytoma and one multiple myeloma. Six cases of KS with injuries spread amongst several organs; all of these patients were male, with ages ranging from 24 to 61-years-old; three had histories of bi/homosexual activity; five involved the digestive tract and only two involved the skin. There were no cases of invasive carcinoma of the uterine cervix. However, three precursor injuries were found: one CIN I in a 27-year-old patient and two CIN II in a 21 and 28-year-old patient.

Tables 4 and 5 present the frequencies of neoplasms according to whether it occurred before or after HAART (introduced in our university hospital in 1997). Although a greater number of neoplasms occurred in the period after the introduction of HAART (1997 to 2008) with a greater number of KS and lymphoid neoplasms, these differences were not statistically significant. We also compared the number of patients with

Table 4

Comparison between the number of cases of HIV with and without neoplasms before and after HAART

\begin{tabular}{llcccc}
\hline \multirow{2}{*}{ Neoplasm } & & \multicolumn{2}{c}{\begin{tabular}{c} 
Before HAART \\
\multicolumn{2}{c}{$(1989-1996)$}
\end{tabular}} & \multicolumn{2}{c}{$\begin{array}{c}\text { After HAART } \\
(1997-2008)\end{array}$} \\
\cline { 3 - 6 } & & $\mathrm{n}$ & $\%$ & $\mathrm{n}$ & $\%$ \\
\hline With & $(\mathrm{n}=58)$ & 13 & $(15.9 \%)$ & 45 & $(25.1 \%)$ \\
Without & $(\mathrm{n}=203)$ & 69 & $(84.1 \%)$ & 134 & $(74.9 \%)$ \\
\hline Total & $(\mathrm{n}=261)$ & 82 & $(100.0 \%)$ & 179 & $(100.0 \%)$ \\
\hline
\end{tabular}

Fisher's exact test $p=0.1096$. HAART: highly active antiretroviral therapy; $n$ : number of cases.

Table 5

Comparison between the number of cases of HIV with and without Kaposi Sarcoma or lymphoid neoplasms before and after HAART

\begin{tabular}{lccccc}
\hline $\begin{array}{l}\text { Kaposi Sarcoma or } \\
\text { lymphoid neoplasias }\end{array}$ & \multicolumn{2}{c}{\begin{tabular}{c} 
Before HAART \\
\multicolumn{2}{c}{$(1989-1996)$}
\end{tabular}} & \multicolumn{2}{c}{\begin{tabular}{c} 
After HAART \\
\multicolumn{2}{c}{$(1997-2008)$}
\end{tabular}} \\
\cline { 3 - 6 } & \multicolumn{2}{c}{$\mathrm{n}$} & $\mathrm{n}$ & $\mathrm{n}$ & $\%$ \\
\hline With & $(\mathrm{n}=13)$ & 2 & $(2.4 \%)$ & 11 & $(6.2 \%)$ \\
Without & $(\mathrm{n}=248)$ & 80 & $(97.6 \%)$ & 168 & $(93.8 \%)$ \\
\hline Total & $(\mathrm{n}=261)$ & 82 & $(100.0 \%)$ & 179 & $(100.0 \%)$ \\
\hline
\end{tabular}

$\mathrm{X}^{2}$ test $p=0.3315$. HAART: highly active antiretroviral therapy; $\mathrm{n}$ : number of cases. 


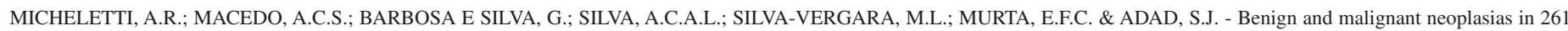
necropsies for HIV-positive patients in the period of 1989 to 2008. Rev. Inst. Med. Trop. São Paulo 53(6): 309-14, 2011.

Table 6

Comparison between the number of cases of HIV with and without benign neoplasias before and after HAART

\begin{tabular}{lccccc}
\hline \multirow{2}{*}{ Benign neoplasias } & \multicolumn{2}{c}{\begin{tabular}{c} 
Before HAART \\
\multicolumn{2}{c}{$(1989-1996)$}
\end{tabular}} & \multicolumn{2}{c}{$\begin{array}{c}\text { After HAART } \\
\text { (1997-2008) }\end{array}$} \\
\cline { 3 - 6 } & \multicolumn{2}{c}{$\mathrm{n}$} & $\%$ & $\mathrm{n}$ & $\%$ \\
\hline With & $(\mathrm{n}=37)$ & 8 & $(9.8 \%)$ & 29 & $(16.2 \%)$ \\
Without & $(\mathrm{n}=224)$ & 74 & $(90.2 \%)$ & 150 & $(83.8 \%)$ \\
\hline Total & $(\mathrm{n}=261)$ & 82 & $(100.0 \%)$ & 179 & $(100.0 \%)$ \\
\hline
\end{tabular}

Fisher's exact test $p=0.1857$. HAART: highly active antiretroviral therapy; $\mathrm{n}$ : number of cases.

Table 7

Comparison between the number of cases of HIV with and without malignant neoplasias before and after HAART

\begin{tabular}{lccccc}
\hline \multirow{2}{*}{ Malignant neoplasias } & \multicolumn{2}{c}{\begin{tabular}{c} 
Before HAART \\
\multicolumn{2}{c}{$(1989-1996)$}
\end{tabular}} & \multicolumn{2}{c}{$\begin{array}{c}\text { After HAART } \\
(1997-2008)\end{array}$} \\
\cline { 3 - 6 } & \multicolumn{2}{c}{$\mathrm{n}$} & $\%$ & $\mathrm{n}$ & $\%$ \\
\hline With & $(\mathrm{n}=21)$ & 4 & $(4.9 \%)$ & 17 & $(9.5 \%)$ \\
Without & $(\mathrm{n}=240)$ & 78 & $(95.1 \%)$ & 162 & $(90.5 \%)$ \\
\hline Total & $(\mathrm{n}=261)$ & 82 & $(100.0 \%)$ & 179 & $(100.0 \%)$ \\
\hline
\end{tabular}

Fisher's exact test $p=0.2316$. HAART: highly active antiretroviral therapy; $\mathrm{n}$ : number of cases.

and without benign and malignant neoplasias before and after HAART (Tables 6 and 7), but it was not significant.

\section{DISCUSSION}

Most of the studies evaluating necropsies on HIV-positive patients involved fewer than 100 necropsias and have described greater frequencies of infections than neoplasia. The frequency of neoplasia has ranged from $3.3 \% \%^{12}$ to $28.9 \%{ }^{20}$. We found a relatively high frequency of benign and malignant neoplasias (22.2\% together) in the present study, but if we took into consideration only malignant neoplasias, it's just $8 \%$.

The total of 261 HIV patients in our study had a mean age of 35.3 \pm 10.7 years, and $73.2 \%$ were male. Comparisons with other Brazilian studies showed that similar mean ages were found: 33.3 years ${ }^{7}$ and 34.8 years ${ }^{12}$. Studies carried out in developed countries presented mean ages slightly greater, of around 38 years ${ }^{20,24,28}$. This may be because of better adherence to treatment, better medical care and longer survival rates. For patients with neoplasms, in particular, there is a tendency for older ages as in our study ${ }^{20,28}$. With regards to gender, there are greater numbers of males as found in our study, ${ }^{72,20}$.

The neoplasias most frequently found were benign and not related to HIV or AIDS until now: hepatic hemangioma (4.2\% of HIV patients) and uterine leiomyoma (15.7\% of HIV-positive women). We did not find papers evaluating the frequency of benign neoplasms in patients with AIDS or HIV infection, but both neoplasms are frequently found among the general population, and their frequencies were within the expected range ${ }^{14,25}$. Following these, the next most frequent tumors were lymphoid neoplasias and $\mathrm{KS}(2.7 \%$ and $2.3 \%$, respectively). There are studies showing greater prevalence of lymphoid tumors ${ }^{7,12,20,27}$ and others presenting greater frequency of $\mathrm{KS}^{1,19,24,28}$ among HIV-positive patients. In our study, these frequencies were similar, as shown by other authors $^{23,32}$. In Brazil, BORGES et al. ${ }^{7}$ described a frequency of KS that was similar to ours (1.9\%), while CURY et al. ${ }^{12}$ did not have any cases of this neoplasia. On the other hand, studies in developed countries have generally found higher frequencies of KS, such as KLATT et al. ${ }^{24}$, with KS occurring in $24.7 \%$ out of 565 necropsies on AIDS patients, and MASLIAH et al. ${ }^{28}$, with KS occurring in $27.1 \%$ out of 390 necropsies on HIV-positive individuals.

We found seven cases of lymphoid tumors (2.7\% of total HIV); there were four NHL (1.5\%), all primary of CNS. Studies in the United States and Europe have presented greater frequencies of NHL than found in Brazilian and African studies. HOFMAN et al. ${ }^{20}$ in France, MARKOWITZ et al. ${ }^{27}$ in the United States and RIDOLFO et al. ${ }^{32}$ in Italy described frequencies of NHL of $14 \%, 9.1 \%$ and $16.5 \%$, respectively. On the other hand, studies carried out in Africa have described frequencies of NHL that were closer to ours, although slightly higher, such as LUCAS et $a l .{ }^{26}$ with $2.8 \%$ and ANSARI et al. ${ }^{1}$ with $3 \%$. In Brazil, studies have described frequencies of NHL that are lower than in the United States and Europe, but higher than we found. BORGES et al. ${ }^{7}$ observed a general frequency of lymphoma of $5.8 \%$, consisting of one HL, one pleomorphic large T-cell NHL and one centroblastic/centrocytic NHL. The four cases of NHL that we described were diffuse large B-cell NHL; three others lymphoid neoplasias were seen: one HL, one plasmablastic plasmacytoma and one multiple myeloma. CURY et al. ${ }^{12}$ found two NHL and one HL among 92 cases of AIDS (3.3\% of lymphoma). We agree with LUCAS et $a l .{ }^{26}$ that the difference observed between developed and underdeveloped countries in relation to the frequency of neoplasia among AIDS patients is associated both with opportunistic infections occurring more frequently and the shorter survival rate among patients in underdeveloped countries.

In an earlier study in which we analyzed the cervicovaginal cytological changes in HIV-positive patients ${ }^{29}$, we found a higher frequency of Human Papillomavirus (HPV) infection and low-grade intraepithelial squamous injuries in the HIV-positive patients than in the HIV-negative patients. However, no such difference was observed in relation to high-grade injuries and invasive carcinoma. In the present study, the frequency of injuries of the uterine cervix was low: only one CIN I and two CIN II, and no cases of invasive carcinoma. Other large series of autopsies on AIDS patients have also not described any cases of invasive carcinoma of the uterine cervix ${ }^{20,24,27}$.

As shown in Table 3, we found other malignant neoplasias than those classically described as associated with AIDS. Other authors have also found $i^{20,24,27}$, however, they have concluded that these neoplasias were within the expected ranges for that age group among the general population. In our study, neoplasias not associated to AIDS until now, both benign and malignant, were within the expected range for the age group, except for two malignant neoplasias: one diffuse gastric adenocarcinoma in a 29-year-old man and one multiple myeloma in a 28-year-old man. These two neoplasms usually are found in patients older than 50-years-old ${ }^{14,25}$.

We compared the frequencies of neoplasia in HIV-positive patients 


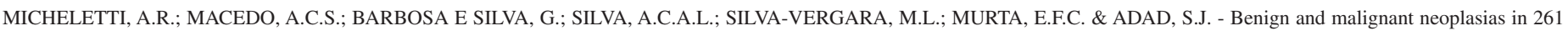
necropsies for HIV-positive patients in the period of 1989 to 2008. Rev. Inst. Med. Trop. São Paulo 53(6): 309-14, 2011.

according to the introduction of HAART. Although there were greater numbers of neoplasia after HAART than before $(25.1 \%$ versus $15.9 \%$, respectively) and also greater numbers of KS and lymphoid neoplasias ( $6.2 \%$ versus $2.4 \%$, respectively), these differences were not statistically significant. Three other studies ${ }^{4,20,24}$ also observed an increased frequency of neoplasia among AIDS patients following the introduction of HAART, mainly because of increases in the numbers of NHL and carcinoma. On the other hand, MASLIAH et $a .^{28}$ did not observe any change in the frequency of neoplasia occurrence among AIDS patients after the introduction of HAART. We also observed higher frequencies of benign neoplasias (16.2\% versus $9.8 \%$, respectively) and malignant neoplasias (9.5\% versus $4.9 \%$, respectively) after HAART, although it was not significant. It could be because of the small number of cases in each group; it is important to also note that we separated the groups according to the date of the necropsy, usually the same as the diagnosis of the tumor, for both malignant and benign neoplasms, but that could influence in the results.

We therefore conclude that the types of neoplasia most frequently found in necropsies on HIV-positive patients in our study were $\mathrm{KS}$ and NHL, which are considered to be associated with AIDS. Other frequently found neoplasia types, particularly hepatic hemangioma and uterine leiomyoma, did not appear to be associated with HIV infection, since they occurred at the same frequency as observed among the general population. Finally, the introduction of HAART into our environment does not appear, so far, to have increased the frequency of neoplasia among HIV-positive patients.

\section{RESUMO}

\section{Neoplasias benignas e malignas em 261 necropsias de pacientes HIV positivos no período de 1989 a 2008}

Tendo em vista que trabalhos sobre necropsias de AIDS analisam apenas neoplasias malignas e que ocorreram alterações após a terapia antiretroviral altamente eficaz (HAART), este estudo foi feito com objetivo de avaliar a frequência de neoplasias benignas e malignas nos períodos pré e pós-HAART. Estudo retrospectivo de 261 necropsias de HIV positivos entre 1989 e 2008 em Uberaba - Brasil. Foram encontradas 66 neoplasias ( 39 benignas, 21 malignas e seis lesões pré-invasivas) em 58 pacientes. As neoplasias malignas mais frequentes foram linfóides, em 2,7\% (quatro linfomas não Hodgkin, um Hodgkin, um mieloma múltiplo e um plasmocitoma plasmoblástico) e, sarcoma de Kaposi, em 2,3\% (seis casos). As benignas mais frequentes foram hemangiomas hepáticos em $11(4,2 \%)$ dos 261 casos e leiomiomas uterinos em $11(15,7 \%)$ das 70 mulheres. No período pré-HAART ocorreram oito $(9,8 \%)$ neoplasias benignas e quatro $(4,9 \%)$ malignas em 82 pacientes; no pós-HAART, $29(16,2 \%)$ benignas e 17 (9,5\%) malignas; entretanto, essas diferenças não foram estatisticamente significantes. Concluímos que a introdução da HAART em nossa região não parece ainda ter alterado a frequência de neoplasias em pacientes HIV.

\section{ACKNOWLEDGEMENTS}

Financial Support: Fundação de Amparo à Pesquisa do Estado de Minas Gerais CDS 2029/05; CDS-APQ 5583-4.01/07; APQ - 01270/08 and Fundação de Ensino e Pesquisa de Uberaba, Proc. 2007/1106.

\section{REFERENCES}

1. Ansari NA, Kombe AH, Kenyon TA, Hone NM, Tappero JW, Nyirenda ST, et al. Pathology and causes of death in a group of 128 predominantly HIV-positive patients in Botswana, 1997-1998. Int J Tuberc Lung Dis. 2002;6:55-63.

2. Barré-Sinoussi F, Chermann JC, Rey F, Nugeyre MT, Chamaret S, Gruest J, et al. Isolation of a T-lymphotrophic retrovirus from a patient at risk for acquired immune deficiency syndrome (AIDS). Science. 1983;220:868-71.

3. Bierhoff E, Weiss A, Tschubel K, Pfeifer U. Epidemiological and pathomorphological autopsy findings in AIDS. Verh Dtsch Ges Pathol. 1991;75:163-5.

4. Bierhoff E, Weiss A, Wolf HK, Ewig S, Rockstroh J, Pfeifer U. Autopsy findings in patients with human immunodeficiency virus infection with emphasis on the risk factor of hemophilia. Gen Diagn Pathol. 1996;141:295-304.

5. Biggar RJ, Jaffe ES, Goedert JJ, Chaturvedi A, Pfeiffer R, Engels EA. Hodgkin lymphoma and immunodeficiency in persons with HIV/AIDS. Blood. 2006;108:3786-91.

6. Biggar RJ, Rosenberg PS, Coté TR. Kaposi's sarcoma and non-Hodgkin lymphoma following the diagnosis of AIDS. Multistate AIDS/Cancer Match Study Group. Int J Cancer. 1996;68:754-8.

7. Borges AS, Ferreira MS, Nishioka SA, Silvestre MTA, Silva AM, Rocha A. Agreement between premortem and postmortem diagnoses in patients with acquired immunodeficiency syndrome observed at a Brazilian teaching hospital. Rev Inst Med Trop Sao Paulo. 1997;39:217-21.

8. Brockmeyer N, Barthel B. Clinical manifestations and therapies of AIDS associated tumors. Eur J Med Res. 1998;23:127-47.

9. Burgi A, Brodine S, Wegner S, Milazzo M, Wallace MR, Spooner K, et al. Incidence and risk factors for the occurrence of non-AIDS-defining cancers among human immunodeficiency virus-infected individuals. Cancer. 2005;104:1505-11.

10. Carlucci M, Cimmino A, Fiore MG, Lepera A, Tantimonaco L, Ricco R. The Pap test in HIV-positive women. Pathologica. 2001;93:651-3.

11. Chaturvedi AK, Pfeiffer RM, Chang L, Goedert JJ, Biggar RJ, Engels EA. Elevated risk of lung cancer among people with AIDS. AIDS. 2007;21:207-13.

12. Cury PM, Pulido CF, Furtado VMG, Palma FMC. Autopsy findings in AIDS patients from a reference hospital in Brazil: analysis of 92 cases. Pathol Res Pract. 2003;199:811-4.

13. Einstein MH, Kadish AS. Anogenital neoplasia in AIDS. Curr Opin Oncol 2004; 16:45562.

14. Fletcher CDM. Diagnostic histopathology of tumors. $2^{\text {nd }}$ ed. Hong Kong: Churchill Livingstone; 2000.2 v, 1851 p.

15. Gates AE, Kaplan LD. AIDS malignancies in era of highly active antiretroviral therapy Oncology (Williston Park). 2002;16:657-65.

16. Goedert JJ, Coté TR, Virgo P, Scoppa SM, Kingma DW, Gail MH, et al. Spectrum of SIDA associated malignant disorders. Lancet. 1998;351:1833-9.

17. Grulich AE, LI Y, McDonald AM, Correll PK, Law MG, Kaldor JM. Decreasing rates of Kaposi's sarcoma and non-Hodgkin's lymphoma in the era of potent combination anti-retroviral therapy. AIDS. 2001;30:629-33.

18. Grulich AE, Wan X, Law MG. Rates of non-SIDA defining cancers in people with SIDA In: First National SIDA Malignancy Conference. Bethesda; 1997. p. 28-30.

19. Guarda LA, Luna MA, Smith JL Jr, Mansell PW, Gyorkey F, Roca AN. Acquired immunodeficiency syndrome: postmortem findings. Am J Clin Pathol. 1984;81:54957. 
MICHELETTI, A.R.; MACEDO, A.C.S.; BARBOSA E SILVA, G.; SILVA, A.C.A.L.; SILVA-VERGARA, M.L.; MURTA, E.F.C. \& ADAD, S.J. - Benign and malignant neoplasias in 261 necropsies for HIV-positive patients in the period of 1989 to 2008. Rev. Inst. Med. Trop. São Paulo 53(6): 309-14, 2011.

20. Hofman P, Saint-Paul MC, Battaglione V, Michiels JF, Loubière R. Autopsy findings in the Acquired Immunodeficiency Syndrome (AIDS). A report of 395 cases from the South of France. Pathol Res Pract. 1999;195:209-17.

21. Hsiao CH, Huang SH, Huang SF, Song CL, Su IJ, Chuang CY, et al. Autopsy findings on patients with AIDS in Taiwan. Zhonghua Min Guo Wei Sheng Wu Ji Mian Yi Xue Za Zhi. 1997;30:145-59

22. Jaffe ES, Harris NL, Stein H, Vardiman JW. World Health Organization classification of tumours. Pathology \& Genetics. Tumours of Haematopoietic and Lymphoid Tissues. Lyon: IARC Press; 2001.

23. Kaiser A, Weng LP, Brockhaus W, Wunsch PH. Opportunistic infections and HIVassociated malignancies. An evaluation of 58 cases within 10 years. Med Klin (Munich). 2000;95:482-6.

24. Klatt EC, Nichols L, Noguchi TT. Evolving trends revealed by autopsies of patients with the acquired immunodeficiency syndrome. 565 autopsies in adults with acquired immunodeficiency syndrome, Los Angeles, Calif, 1982-1993. Arch Pathol Lab Med. 1994;118:884-90.

25. Kumar V, Abbas AK, Fausto N. Robbins \& Cotran pathologic basis of diseases. $7^{\text {th }}$ ed. Rio de Janeiro: Elsevier; 2005.

26. Lucas SB, De Cock KM, Peacock C, Diomande M, Kadio A. Effect of HIV infection on the incidence of lymphoma in Africa. East Afr Med J. 1996;73(5 Suppl):S29-30.

27. Markowitz GS, Conception L, Factor SM, Borczuk AC. Autopsy patterns of disease among subgroups of an inner-city Bronx AIDS population. J Acquir Immunedefic Syndr Human Retrovirol. 1996;13:48-54.
28. Masliah E, Teresa RM, Mallory ME, Hansen L. Changes in pathological findings at autopsy in AIDS cases for the last 15 years. AIDS. 2000;14:69-74.

29. Micheletti AM, Dutra VF, Murta EF, Paschoini MC, Silva-Vergara ML, Barbosa E Silva $\mathrm{G}$, et al. Cervicovaginal cytological abnormalities in patients with human immunodeficiency virus (HIV) infection, in relation to disease stage, CD4 cell count and viral load. Diagn Cytopathol. 2009;37:164-9.

30. Mohar A, Volkow P, Sánchez Mejorada G, Sada E, Soto JL, Pérez F, et al. Sida y neoplasias en México. Salud Pública México. 1995;37:533-8.

31. Moskowitz L, Hensley GT, Chan JC, Adams K. Immediate causes of death in acquired immunodeficiency syndrome. Arch Pathol Lab Med. 1985;109:735-8.

32. Ridolfo AL, Santambrogio S, Mainini F, Vago L, Gervasoni C, Gori A, et al. High frequency of non-Hodgkin's lymphoma in patients with HIV-associated Kaposi's sarcoma. AIDS. 1996;10:181-5.

33. Sehonanda A, Choi YJ, Blum S. Changing patterns of autopsy findings among persons with acquired immunodeficiency syndrome in an inner-city population. A 12-year retrospective study. Arch Pathol Lab Med. 1996;120:459-64.

34. Smith C, Lilly S, Mann KP, Livingston E, Myers S, Lyerly HK, et al. AIDS-related malignancies. Ann Med. 1998;30:323-44.

35. Walewska-Zielecka B, Kaminski Z, Nowoslawski A. AIDS pathology: infections and neoplasms in 55 fatal AIDS cases. A postmortem study. Pol J Pathol. 1996;47:163-70.

Received: 21 July 2011

Accepted: 4 October 2011 